\title{
PENGARUH LAMA PERAWATAN TERHADAP INDEKS PLATELET PASIEN DEMAM BERDARAH DENGUE (DBD) DI RUMAH SAKIT ISLAM JEMURSARI SURABAYA
}

\author{
Ruri Arinil Khoiro*, Gilang Nugraha, Wieke Sri Wulan \\ Prodi D-IV Analis Kesehatan Surabaya, Fakultas Kesehatan \\ Universitas Nahdlatul Ulama Surabaya \\ J1. Jemursari Nomor 51-57, Surabaya, Indonesia \\ *E-mail: ruri.nk15@student.unusa.ac.id
}

\begin{abstract}
Dengue Hemorrhagic Fever (DHF) is one of the most tropical infectious diseases in Indonesia caused by the dengue virus and mediated by the bites of Aedes aegypti and Aedes albopictus mosquitoes. One of the clinical symptoms of dengue disease is a decrease in the number of blood platelets. Several platelet indices are known as indicators of platelet activation, namely Mean Platelet Volume (MPV), and Platelet Distribution Width (PDW). DHF patients who experience treatment at the hospital only monitor the low platelet count in healing. The purpose of this study was to determine the effect of length of treatment on the MPV Platelet Index and PDW of DHF patients. Data were obtained by taking primary data at Jemursari Islamic Hospital Surabaya. This research is a OneShot Case Studies research with a descriptive-analytic method and Cross-sectional design in DHF patients at Jemursari Islamic Hospital Surabaya. The sampling technique uses an accidental sampling technique. Analysis of MPV and PDW data using the Wilcoxon Sign Rank Test nonparametric test. The test was used to see the effect of patient length of care on the MPV and PDW platelet index with a significance level of $\alpha=0.05$. The results of the Wilcoxon Sign Rank Test on the $M P V$ show a significance of $(\rho=0.845)$, and the results of the Wilcoxon Sign Rank Test statistic on the PDW show a significance of $(\rho=0.469)$. Based on the results of the study, it can be concluded that there is no effect on the length of treatment on the MPV and PDW Platelet Index in DHF patients at Jemursari Hospital Surabaya.
\end{abstract}

Keywords: Platelet Index, Dengue, Duration of Treatment

\begin{abstract}
ABSTRAK
Penyakit Demam Berdarah Dengue (DBD) merupakan salah satu penyakit infeksi tropis terbanyak di Indonesia yang disebabkan oleh virus dengue dan diperantarai oleh gigitan nyamuk Aedes aegypti dan Aedes albopictus. Salah satu gejala klinis dari penyakit dengue adalah menurunnya jumlah trombosit darah. Terdapat beberapa indeks trombosit yang diketahui sebagai indikator aktivasi trombosit, yaitu Mean Platelet Volume (MPV), dan Platelet Distribution Width (PDW). Pasien DBD yang mengalami perawatan di Rumah Sakit hanya memantau jumlah trombosit yang rendah selama proses penyembuhannya. Tujuan dari penelitian ini untuk mengetahui pengaruh lama perawatan terhadap Indeks Platelet MPV dan PDW pasien DBD. Data diperoleh dengan pengambilan data primer di Rumah Sakit Islam Jemursari Surabaya. Penelitian ini merupakan jenis penelitian One Shot Case Study dengan metode deskriptif analitik dan desain Cross-sectional pada pasien DBD di Rumah
\end{abstract}


Sakit Islam Jemursari Surabaya. Teknik pengambilan sampel menggunakan teknik accidental sampling. Analisis data MPV dan PDW menggunakan uji non-parametrik Wilcoxon Sign Rank Test. Uji tersebut digunakan untuk melihat pengaruh lama perawatan pasien pada indeks platelet MPV dan PDW dengan tingkat kemaknaan $\alpha=0,05$. Hasil uji statistik Wilcoxon Sign Rank Test pada MPV menunjukkan signifikansi sebesar $(\rho=0,845)$, dan hasil uji statistik Wilcoxon Sign Rank Test pada PDW menunjukkan signifikansi sebesar $(\rho=0,469)$. Berdasarkan hasil penelitian, dapat ditarik kesimpulan bahwa tidak terdapat pengaruh lama perawatan terhadap Indeks Platelet MPV dan PDW pada pasien DBD di RSI Jemursari Surabaya.

Kata kunci: Indeks Platelet, Dengue, Lama Perawatan.

\section{PENDAHULUAN}

Penyakit demam berdarah dengue (DBD) atau dengue hemmorhagic fever (DHF) merupakan salah satu penyakit infeksi tropis terbanyak di Indonesia yang disebabkan oleh virus dengue. Penularan virus ini diperantarai oleh gigitan nyamuk Aedes aegypti dan Aedes albopictus. Infeksi virus dengue pada manusia mengakibatkan manifestasi klinis yang bervariasi dimulai penyakit paling ringan (mild undifferentiated febrile illness), demam dengue (DD), demam berdarah dengue (DBD), sampai dengue shock syndrome (DSS). ${ }^{1}$

Kematian akibat DBD dikatakan tinggi jika angka kematian mencapai lebih dari $1 \%$. Tahun 2015 ada lima provinsi yang memiliki nilai angka kematian tertinggi, yaitu Maluku (7,69\%), Gorontalo (6,06\%), Papua Barat (4,55\%), Sulawesi Utara (2,33\%), dan Bengkulu (1,99\%) (Kemenkes RI, 2016). Morbiditas dan mortalitas DBD bervariasi, disebabkan oleh bermacam faktor antara lain status, umur penduduk, kepadatan vektor, tingkat penyebaran virus dengue, prevalensi serotipe virus dengue, dan kondisi meteorologis. ${ }^{1}$
Salah satu gejala klinis dari penyakit dengue adalah menurunnya jumlah trombosit darah. Nilai trombosit akan menurun pada masa demam dan mencapai nilai terendah pada masa syok (Kirana et al., 2018). Terdapat beberapa indeks trombosit yang diketahui sebagai indikator aktivasi trombosit, yaitu Mean Platelet Volume (MPV), dan Platelet Distribution Width (PDW). Semakin tinggi kadar MPV mengindikasikan banyaknya trombosit berukuran besar yang merupakan tanda peningkatan pergantian trombosit. Sedangkan Platelet Distribution Width (PDW) mengindikasikan tingkat anisositosis dari trombosit. $^{2}$

Penanganan terapi untuk pasien DBD bersifat suportif dan simtomatis. Simtomatis mengatasi keadaan sesuai dengan keluhan dan gejala klinis dari pasien, sedangkan secara suportif mengatasi kehilangan cairan plasma dan kekurangan cairan. Penatalaksanaan keduanya ditujukan untuk mengganti cairan akibat kebocoran plasma dan memberikan terapi substitusi komponen darah bilamana diperlukan. $^{3}$ 
Berdasarkan hal itu, peneliti ingin melakukan penelitian pengaruh Indeks Platelet pada fase penyembuhan selama perawatan pasien DBD selama di Rumah Sakit Islam Jemursari Surabaya.

\section{METODE PENELITIAN}

Penelitian ini merupakan jenis penelitian One Shot Case Study. Desain penelitian ini adalah desain Cross Sectional yang menekankan pada rancangan waktu penelitian atau observasi pada variabel data dengan metode deskriptif analitik.

Lokasi penelitian dilaksanakan di Rumah Sakit Islam Jemursari Surabaya yang dilaksanakan mulai tanggal 18 Februari-10 Maret 2019. Populasi dalam penelitian ini merupakan pasien yang menderita penyakit DBD di RSI Jemursari Surabaya. Sampel yang digunakan merupakan pasien DBD yang telah melaksanakan pemeriksaan di Laboratorium RSI Jemursari Surabaya.

Penentuan dalam pengambilan sampel dalam penelitian ini dengan teknik accidental sampling. Pengumpulan data diperoleh dari data primer, yaitu data yang diperoleh atau didapatkan oleh peneliti berasal dari data langsung dari pasien yang terdiagnosis DBD serta memantau catatan medical record pasien selama perawatan untuk mengetahui perkembangan Indeks Platelet pasien selama penelitian di Rumah Sakit Islam Jemursari Surabaya
Semua data yang dikumpulkan dilakukan pemaparan pada setiap variabel yang diperoleh lalu disusun secara berkelompok. Hasil dari penelitian dijabarkan dalam bentuk tabel kemudian untuk mengetahui uji apa yang akan dipakai peneliti, peneliti melakukan uji normalitas dan tidak dilanjutkan dengan uji homogenitas. Hal tersebut dikarenakan data berdistribusi tidak normal dan tidak dapat dilakukan uji homogenitas. Data yang tidak normal tersebut dilakukan uji statistik menggunakan SPSS dengan uji Wilcoxon Sign Rank Test.

\section{HASIL DAN PEMBAHASAN}

Sampel yang di dapatkan sebanyak 60 pasien di antaranya 30 pasien DBD pada hari ke3 dengan jumlah MPV sebanyak 30 sampel dengan rata-rata sebesar 10,64 fL dan jumlah PDW sebanyak 19 Sampel dengan rata-rata PDW pasien sebesar 21,9 (10(GSD)). Kemudian 30 pasien DBD pada hari ke-5 dengan jumlah MPV sebanyak 30 sampel dengan rata-rata sebesar 11,68 fL dan jumlah PDW sebanyak 19 sampel dengan rata-rata 21,8 (10(GSD)).

Penelitian untuk hari ke-7 ditiadakan karena sampel yang di dapat hanya 7 sampel pasien dengan jumlah MPV sebanyak 7 sampel dan jumlah PDW sebanyak 7 Sampel. Pihak dari Rumah Sakit juga menjelaskan bahwa pasien yang di Rawat di RSI Jemursari Surabaya ratarata pasien dengan bantuan BPJS yang mana sebagian besar pasien BPJS yang dirawat di RSI 
Jemursari Surabaya tidak sampai 7 hari sudah diperkenankan untuk pulang. DBD dibagi menjadi 3 fase, diantara-nya fase febril, fase kritis dan fase penyembuhan. ${ }^{4}$ Biasanya pada fase febril pasien mengalami perawatan di rumah, saat pasien dibawa ke rumah sakit, biasanya pasien saat memasuki fase kritis atau fase penyembuhan. Jadi pasien saat dirawat di rumah sakit tidak sampai selama 7 hari.

\section{Karakteristik Pemeriksaan}

Usia

Tabel 1. Distribusi Sampel Menurut Usia

\begin{tabular}{ccr}
\hline Usia (Tahun) & $\mathrm{n}$ & $\%$ \\
\hline $6-11$ & 2 & 6,7 \\
$12-25$ & 10 & 33,3 \\
$26-45$ & 12 & 40,0 \\
$46-65$ & 5 & 16,7 \\
$>65$ & 1 & 3,3 \\
\hline Total & 30 & 100,0 \\
\hline
\end{tabular}

Pasien laki-laki yang menderita DBD sebanyak $50 \%$ dan pasien perempuan yang terkena DBD sebanyak 50\%. Usia yang rentan terkena penyakit DBD adalah pasien dengan usia dewasa (26-45 tahun) sebanyak 40\% dan remaja (12-25 tahun) sebanyak 33,3\%.

Usia terbanyak yang terkena DBD pada penelitian terjadi pada rentan usia dewasa (2645 tahun) sebanyak $40 \%$ dan remaja (12-25 tahun) sebanyak 33,3\%. Penyebab banyaknya umur dewasa dan remaja dijelaskan oleh WHO 2nd edition (1997) bahwa salah satunya adalah aktivitas di luar rumah yang berpeluang terinfeksi virus dengue dan kurang waspada dalam perlindungan diri dari gigitan nyamuk. ${ }^{5}$
Hasil dari penelitian Djati (2010) menjelaskan, bahwa kelompok usia dewasa dan remaja masuk dalam usia produktif yang memiliki kegiatan pada siang hari lebih banyak baik di dalam ruangan maupun di luar ruangan, mobilisasi tinggi, interaksi dengan orang lain juga tinggi, sehingga memudahkan vektor nyamuk Aedes aegypti untuk menularkan virus dengue. Hal tersebut juga ditunjang oleh penelitian di Yogyakarta oleh Djati dkk (2010) yang menyebutkan kondisi kerja seperti duduk diam dan aktivitas di dalam gedung memiliki risiko lebih tinggi terpapar virus dengue dibandingkan dengan aktivitas berkeliling lapangan. ${ }^{5}$ Penelitian ini sesuai dengan penelitian Fitri (2005) menyatakan bahwa dalam penelitiannya di Pekanbaru memperlihatkan bahwa proporsi penderita DBD lebih banyak pada usia remaja atau lebih dari 15 tahun. ${ }^{5}$ Hasil penelitian ini juga diperkuat dengan hasil penelitian pada tahun 2000 di Jawa Timur menunjukkan kasus DBD Cenderung meningkat pada usia kelompok dewasa dan remaja. ${ }^{5}$

\section{Jenis kelamin}

Tabel 2. Distribusi Sampel Menurut Jenis Kelamin

\begin{tabular}{ccc}
\hline Jenis Kelamin & $\mathrm{n}$ & $\%$ \\
\hline Laki-laki & 15 & 50,0 \\
Perempuan & 15 & 50,0 \\
\hline Total & 30 & 100,0 \\
\hline
\end{tabular}

Jenis Kelamin pada penelitian ini tidak terdapat perbedaan yang jauh antara laki-laki dan perempuan. Banyak pasien laki-laki yang 
terkena DBD sebanyak 15 pasien (50\%) dan perempuan sebanyak 15 pasien (50\%). Hasil tersebut tidak sesuai dengan penelitian yang dilakukan Saraswati dan Mulyantari yang menjelaskan bahwa lelaki lebih rentan terhadap DBD terkait dengan aktivitas atau pekerjaan di luar rumah saat siang hari yang dimana waktu tersebut merupakan waktu paparan dari vektor virus dengue. ${ }^{6}$ Hasil ini diperkuat dengan Data Kesehatan Indonesia yang dikeluarkan oleh Kementerian Kesehatan Republik Indonesia (2012) bahwa jumlah kasus DBD di Indonesia pada tahun 2011 lebih banyak terjadi pada lelaki yaitu $51,14 \%$ dibandingkan dengan perempuan 48,86\%. ${ }^{6}$ Vebriani, dkk (2016) dalam penelitiannya juga menjelaskan bahwa jenis kelamin pasien DBD lebih banyak pasien lakilaki sedangkan wanita. ${ }^{5}$

\section{Hasil uji statistik indeks platelet MPV}

Tabel 3. Uji Statistik Indeks Platelet MPV

\begin{tabular}{cccl}
\hline No & $\begin{array}{c}\text { Uji Wilcoxon } \\
\text { Sign Rank Test }\end{array}$ & p-value & Keterangan \\
\hline 1 & Pengaruh pada & 0,845 & Tidak \\
& Perawatan hari & & terdapat \\
& ke-3 dan hari & & pengaruh \\
& ke-5 & \\
\hline
\end{tabular}

Hasil yang didapatkan pada indeks platelet MPV nilai signifikansinya sebesar 0,845, maka dapat disimpulkan bahwa tidak terdapat pengaruh lama perawatan di hari ke-3 dan ke-5 pada pasien DBD terhadap Indeks Platelet MPV.
Tabel 4. Uji Statistik Indeks Platelet PDW

\begin{tabular}{lcll}
\hline No & Uji Wilcoxon & p-value & Keterangan \\
& Sign Rank Test & & \\
\hline 1 & Pengaruh pada & 0,469 & Tidak \\
& Perawatan hari & & terdapat \\
& ke-3 dan hari & & pengaruh \\
& ke-5 & & \\
\hline
\end{tabular}

Hasil di dapatkan pada indeks platelet PDW nilai signifikansinya sebesar 0,469 , maka dapat disimpulkan bahwa tidak terdapat pengaruh lama perawatan di hari ke-3 dan ke-5 pada pasien DBD terhadap Indeks Platelet PDW.

Uji pada indeks platelet PDW menggunakan sampel sebanyak 19 pasien di hari ke-3 dan 19 pasien di hari ke-5, hal tersebut dikarenakan nilai dari PDW yang tidak muncul pada beberapa pasien, sehingga mengharuskan pengurangan sampel dalam uji statistiknya. Peneliti Kaito dkk (2005) mengatakan pada alat Hematology Analyzer Sysmex-XE2100, nilai PDW dapat di analisis melalui sebaran distribusi ukuran trombosit pada histogram hasil pemeriksaan. Persebaran trombosit dapat terbaca dari lebar distribusi platelet pada histogram minimal sebesar 20\%. ${ }^{7}$ Pada penelitian ini, Tidak terbacanya nilai PDW pada alat Hematology Analyzer dapat dilihat dari histogram platelet pada print-out Hematology Analyzer, bahwa pada histogram tersebut indeks platelet yang tidak terbaca distribusinya tidak sampai $20 \%$. 
Jadi, selama pasien dalam masa perawatan, nilai MPV dan PDW tidak berpengaruh dalam masa penyembuhan pasien. Kirana (2018) mengatakan bahwa terdapat hubungan negatif kuat antara nilai MPV terhadap jumlah trombosit pada pasien DBD dan korelasi negatif lemah antara nilai PDW terhadap jumlah trombosit. ${ }^{1}$ Jadi Indeks Platelet pasien juga tidak berpengaruh pada jumlah trombosit pasien DBD. Mukker dan Kiran mengungkapkan bahwa kasus DBD dikaitkan dengan nilai MPV rendah dan nilai PDW yang tinggi. ${ }^{8}$

Hasil rata-rata pada pasien yang di rawat di RSI Jemursari Surabaya, dapat dilihat bahwa apabila nilai MPV naik maka nilai pada PDW akan turun, begitu pula sebaliknya, apabila nilai PDW naik, maka nilai MPV akan turun. Seperti contoh pasien dengan identitas "AA" pada hari ke-3, nilai MPV sebesar 11,5 fL dan nilai PDW sebesar 22,1 (10(GSD)), sedangkan hari ke-5, nilai MPV sebesar 10,3 fL dan nilai PDW sebesar 22,6 (10(GSD)). Hal ini sesuai dengan penelitian yang di lakukan Gunawan bahwa nilai PDW dan MPV berada dalam hubungan terbalik dengan jumlah trombosit, akan tetapi efek biologis, arti klinis dan hubungannya dengan perubahan jumlah trombosit dengan DBD masih belum jelas. $^{9}$

Ketika mengolah sampel yang ada, ada beberapa hasil nilai MPV yang tidak dapat terbaca oleh alat dan hanya melambangkan simbol ">>> yang menandakan bahwa tingginya nilai MPV pasien. Nilai Normal untuk MPV pada alat Cell Dyn Ruby berkisar antara 4.3-17.2 fL Untuk mengetahui berapa hasil nilai dari MPV yang kosong tersebut, maka peneliti menggunakan rumus yang berasal dari mencari nilai PCT yang diformulasikan sebagai berikut $\mathrm{PCT}=$ platelet count $\times \mathrm{MPV} / 10.000$, maka untuk mencari nilai MPV, formulanya berubah menjadi MPV $=$ PCT $\times 10.000 /$ platelet count.$^{10}$

\section{SIMPULAN DAN SARAN}

\section{Simpulan}

Berdasarkan hasil penelitian dan pembahasan, maka dapat disimpulkan bahwa tidak terdapat pengaruh lama perawatan terhadap indeks platelet pasien Demam Berdarah Dengue (DBD) di Rumah Sakit Islam Jemursari Surabaya.

\section{Saran}

Berdasarkan hasil penelitian dan pembahasan, maka terdapat saran dari peneliti yang perlu ditambahkan untuk peneliti lain sebaiknya melakukan penelitian lebih lanjut tentang pengaruh Indeks Platelet terhadap pasien DBD, seperti penggunaan kuesioner untuk mengetahui perkembangan setiap selesai melakukan pemeriksaan.

\section{REFERENSI}

1. Kirana, P., Tjiptaningrum A., \& Graharti R. Hubungan Nilai Mean Platelet Volume (MPV) dan Platelet Distribution Width (PDW) Terhadap Jumlah Trombosit Pada Pasien Demam /Berdarah Dengue (DBD) di RS Urip Sumoharjo. 2018;7(2). 
2. Rechiniski T. Prognostic value of platelet indices after acute myocardial infarction treated with primary percutaneous coronary intervention. Cardiology. 2013;20(5):4918.

3. Yusriana CS. Pola Pengobatan Penyakit Demam Berdarah Dengue (DBD) Pada Pasien Anak Di Instalasi Rawat Inap RSIY PDHI Yogyakarta Periode Februari 2010. 2010;4.

4. Japiter C. Skripsi Aktivasi Platelet Sebagai Respons Pada Demam Berdarah Dengue (DBD). In Medan: Universitas Sumatera Utara; 2017.

5. Saraswati LPC\& MKN. Prevalensi Demam Berdarah Dengue (DBD) Primer Dan Sekunder Berdasarkan Hasil Pemeriksaan Serologis Di Rumah Sakit Balimed Denpasar. E-Jurnal Med. 2017;

6. Kaito, K., Otsubo, H., Usui, N., Yoshida, M., Tanno, J \& Kurihara E. Platelet Size Deviation Width, Platelet Large Cell Ratio, and Mean Pletelet Volume Have Sufficient Sensitivity and Specivity in th Diagnosis of Immune Thrombocytopenia. J Haematol. 2005;128.

7. Mukker $P$ \& Kiran S. Platelet Indices Evaluation in Patient with Dengue Fever. Int J Res Med Sci. 2018;6.

8. Gunawan, S., Sutanto, F. C., Tatura, S. N.N, \& Mantik MFJ. Platelet Distribution Width dan Mean Platelet Volume: Hubungan dengan Derajat Penyakit Demam Berdarah Dengue. Sari Pediatr. 2010;12(2):76-7.

9. Budak, Y. U, Polat, M., \& Huysal K. The Use Of Platelet Indices, Plateletcrit, Mean Platelet Volume And Platelet Distribution Width In Emergency Non Traumatic Abdominal Surgery: A Systematic Review. Biochem Medica. 2016;26(2):93-178.

10. Vebriani, L., Wardana Z. \& F. Karakteristik Hematologi Pasien Demam Berdarah Dengue Di Bagian Penyakit Dalam RSUD Arifin Achmad Provinsi Riau Periode 1 Januari-31 Desember 2013. 2016;3(1). 